\title{
Usefulness of Fibrin Glue in Transantral Orbital Floor Fracture Repair Using Bioresorbable Panel
}

\author{
Tae Jung Park ${ }^{1}$, Tae Young Jung ${ }^{1}$, Bo Young Kim ${ }^{1}$, Seok Kim ${ }^{1}$, \\ Min Joon Kim ${ }^{1}$, Jae Hwan Kwon ${ }^{2}$, Kyu Sup Cho ${ }^{3}$, and Soo Keun Kong ${ }^{3}$ \\ ${ }^{I}$ Department of Otorhinolaryngology-Head and Neck Surgery, Maryknoll Medical Center, Busan; and \\ ${ }^{2}$ Department of Otorhinolaryngology-Head and Neck Surgery, Kosin University College of Medicine, Busan; and \\ ${ }^{3}$ Department of Otorhinolaryngology-Head and Neck Surgery, Pusan National University School of Medicine and \\ Medical Research Institute, Busan, Korea
}

\section{생체 흡수성 고정판을 이용한 경상악동 안와하벽골절 정복술에서 피브린 글루의 유용성}

박태정 ${ }^{1} \cdot$ 정태영 ${ }^{1} \cdot$ 김보영 ${ }^{1} \cdot$ 김 석 $^{1} \cdot$ 김민준 $^{1} \cdot$ 권재환 $^{2} \cdot$ 조규섭 $^{3} \cdot$ 공수근 $^{3}$

메리놀병원 이비인후과, ${ }^{1}$ 고신대학교 의과대학 이비인후과학교실, ${ }^{2}$ 부산대학교 의학전문대학원 이비인후과학교실

\author{
Received August 5, 2016 \\ Revised October 20, 2016 \\ Accepted November 2, 2016 \\ Address for correspondence \\ Soo Keun Kong, MD, PhD \\ Department of Otorhinolaryngology- \\ Head and Neck Surgery, \\ Pusan National University \\ School of Medicine and \\ Medical Research Institute, \\ 179 Gudeok-ro, Seo-gu, \\ Busan 49241, Korea \\ Tel +82-51-240-7335 \\ Fax $+82-51-246-8668$ \\ E-mail entkong@gmail.com
}

Background and Objectives The purpose of this study was to evaluate the advantages and limitations of using fibrin glue for securing bioresorbable panels to reconstruct the fractured orbital floor by transantral approach.

Subjects and Method A retrospective study was conducted from July 2009 to July 2015 in 35 patients with pure orbital floor fractures. Nineteen patients underwent reduction surgery for inserting the bioresorbable panel and 16 patients underwent reduction surgery using fibrin glue for securing the bioresorbable panel via a transantral approach. In both groups, a chart review of preoperative and postoperative ocular symptoms, operation records, and complications was conducted.

Results There was no significant difference between two groups in the demographic data of patients. Comparing the surgical outcomes between two groups, diplopia and mean discrepancy between fractured bone chip and intact orbital floor based on computed tomography scans showed much better results in the group that used bioresorbable panel secured by fibrin glue than in the bioresorbable only group. Furthermore, we carried out revision operations in six cases in the bioresorbable panel only group, where we found that the main cause of fracture to be the dislocation of bioresorbable panel. On the other hand, in the bioresorbable panel secured by the fibrin glue group, there were no reoperation and postsurgical complications.

Conclusion During the course of the study, we sensed orbital floor fracture repair using bioresorbable panel secured by fibrin glue via a transantral approach as an easy and effective technique with good postoperative results, and minimal implant related complications. This novel procedure is recommended as a surgical option for the reduction of orbital floor fractures, especially in large and posterior fractures.

Korean J Otorhinolaryngol-Head Neck Surg 2017;60(2):69-75

Key Words Blow-out fracture $\cdot$ Fibrin glue.

\section{서 론}

안와하벽골절을 정복하는 접근 방법은 크게 경안와(transorbital), 경상악동(transantral), 비강내(intranasal) 접근법으
로 나눌 수 있으며, 골절 양상에 따른 술자의 경험이나 전공, 선호도에 따라 결정하게 된다. 안와하벽의 골절이 크고 비교 적 후방에 위치한 경우 경안와 접근법만으로 정복이 잘 되지 않는데 이때 경상악동 접근법으로 상악동 안으로 탈출된 골 
편 및 안와 조직을 정복한 후 골절 부위를 지지하면 쉽게 정 복할 수 있다. ${ }^{1)}$ 안와하벽골절의 골결손 부위는 뼈나 연골과 같은 자가조직, 인공 삽입물 등 다양한 재료를 사용하여 막 아줄 수 있다. 하지만, 삽입물을 지지할 남아있는 구조물이 제한되어 있을 경우 요오드포름을 적신 거즈나, 수산화 인회 석(hydroxyapatite) 블록, 실리콘 블록 혹은 튜브를 상악동 에 충전하기도 하고 비강내 접근을 통해 풍선 또는 요도 카테 터를 상악동 내에 삽입하여 부풀리는 방법으로 이식물의 탈 출을 방지하기도 한다. ${ }^{2-4)}$ 이 충전 방식은 상악동 내 충전물을 제거하는 2 차 수술을 해야 하고, 지지하는 삽입물이 전위되어 재수술을 해야 할 가능성이 있으며, 삽입물로 인한 이물 반응 으로 상악동 내 염증이 발생할 수 있다. ${ }^{5)}$ 저자들은 이러한 단 점을 해소하기 위해 경상악동 접근법으로 안와하벽골절의 골결손 부위에 생체 흡수성 고정판(Macropore ${ }^{\circledR}$; Medtronic Inc., Minneapolis, MN, USA)을 삽입하고 피브린 글루(Greenplast kit ${ }^{\circledR}$; Greencross Corp., Yongin, Korea)를 이용하여 고 정하였으며 그 방법과 유용성을 소개하고 생체 흡수성 고정 판만을 사용했던 경우와 결과를 비교하고자 한다.

\section{대상 및 방법}

\section{대 상}

2009년 7월부터 2015년 7월까지 본원 이비인후과에 내원하 여 안와하벽골절로 진단 및 수술한 환자는 총 145 명이었다. 이 중 협골 골절, 상악골 골절, 안와 내벽 골절 등이 동반되었 거나, 비흡수성 고정판, 상악동 충전법을 사용한 경우는 제 외하고 골결손 부위를 막기 위한 삽입물을 지지할 구조물이 제한되어 있는 안와하벽 $50 \%$ 이상의 큰 골절이면서 안와하 벽 후방 골절인 경우, 환자가 피부 절개를 원하지 않아 경상악 동으로 접근하여 생체 흡수성 고정판을 삽입한 35 명의 환자를
대상으로 하였다. 수술은 본원 이비인후과에서 안와 골절 수 술을 3년 이상 전담한 경험이 있는 술자에 의해 시행되었으며, 19 명은 생체 흡수성 고정판만을 사용하였고 16명은 생체 흡 수성 고정판을 삽입하고 피브린 글루를 이용하여 고정하였 고 의무기록지 검토를 통한 후향적 분석을 시행하였다.

\section{수술 방법}

생체 흡수성 고정판만을 사용한 수술과 생체 흡수성 고정 판을 삽입하고 피브린 글루를 이용하여 고정한 수술 모두 기 관 내 삽관에 의한 전신 마취하에서 경상악동 접근법으로 안 와하벽골절 정복술을 시행하였다. 환측의 치은 협구를 따라 3 4 cm를 절개한 후 freer 거상기로 골막을 박리하여 상악 동 전벽을 노출시키고 전기톱으로 전벽에 $2 \times 2 \mathrm{~cm}$ 크기의 골 조각을 떼어내 창을 낸 다음 $0^{\circ}$ 내시경으로 탈출된 안와 조 직을 확인하고 견인기로 정복 후 생체 흡수성 고정판을 골절 의 경계보다 1 2 $\mathrm{mm}$ 크게 재단하여 삽입함으로써 골결손 부위를 막아주었다(Fig. 1A and B). ${ }^{6}$ 파열된 상악동 내의 점 막은 삽입된 생체 흡수성 고정판 위로 덮어 주었다. 정복 후 강 제견인검사(forced duction test)를 시행하여 안구운동의 기계 적 장애 유무를 검사하였으며 안구압박시험을 시행하여 생 체 흡수성 고정판의 안정성을 확인하였다. 생체 흡수성 고정 판을 삽입하고 피브린 글루를 이용하여 고정한 수술에서는 생체 흡수성 고정판 삽입 후 피브린 글루가 흘러내리지 않도 록 환자 체위를 Trendelenburg 자세로 바꾼 후 안와하벽 전 체에 피브린 글루를 도포하여 생체 흡수성 고정판이 이탈하 지 않도록 고정하였다(Fig. 1C). 상악동 전벽에서 떼어낸 골 조각은 생리식염수에 보관하였다가 수술을 마칠 때 미니 플레 이트(mini plate) 시스템을 사용하여 원래의 자리에 고정하였 으며 치은 협구 절개 부위는 흡수성 봉합사(Vicryl plus ${ }^{\circledR} 4-0$; Ethicon, Somerville, NJ, USA)를 사용하여 봉합하였다.
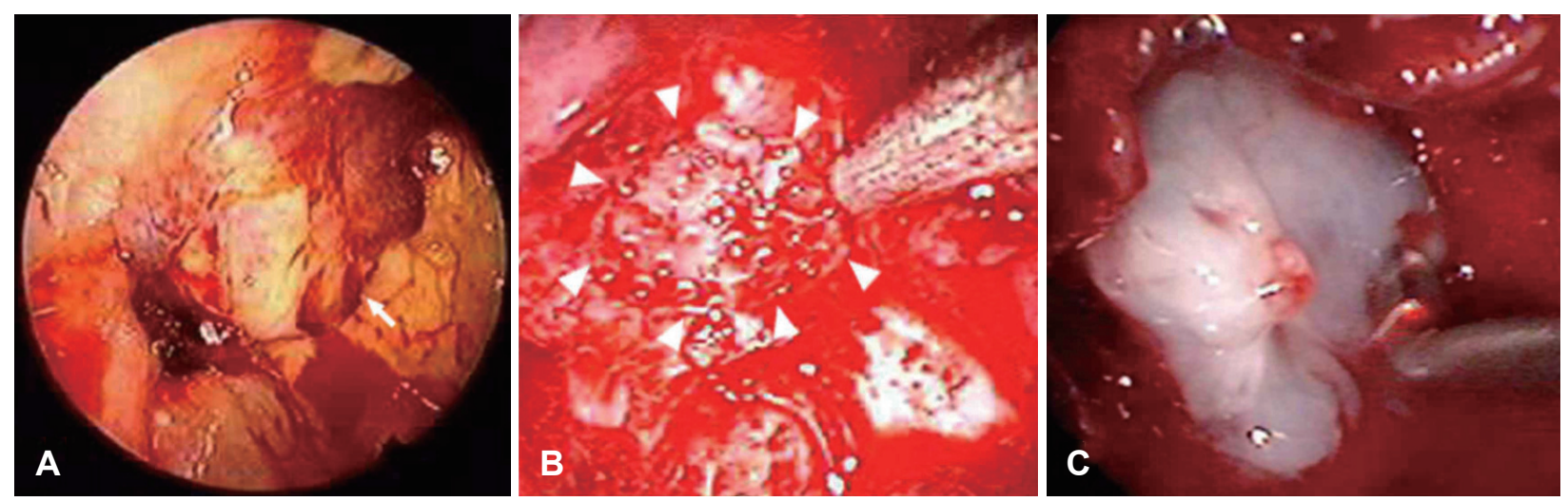

Fig. 1. Intraoperative endoscopic views of the left maxillary sinus of an orbital floor fracture, through the antral window. The orbital floor was fractured, and periorbital soft tissue was herniated into the maxillary sinus (arrow) (A). The fractured orbital contents were reduced to anatomic position and a bioresorbable panel (arrowheads) was placed under the fractured bone (B). Fibrin glue were sprayed to secure bioresorbable panel for support the reduced orbital floor (C). 


\section{분석 방법}

술 전에 모든 환자에서 안면부 전산화단층촬영을 시행하 여 안와하벽골절의 형태 및 부위를 확인하였으며 술 후 5일 이내에 안면부 전산화단층촬영을 통해 안와하벽골절 정복 상태를 확인하였다.

안와하벽골절의 정도와 정복 상태는 다음과 같이 분류하였 다. Grade I은 정상 안와하벽과 $2 \mathrm{~mm}$ 미만의 차이를 보이는 경우 그리고 grade II는 정상 안와하벽과 $2 \mathrm{~mm}$ 이상의 차이 를 보이는 경우로 규정하였다(Fig. 2). ${ }^{7}$

안과에 의뢰하여 시력, 안구운동장애, 복시, 안구함몰 등을 술 전, 술 후 1주일, 1 개월, 3 개월, 6 개월, 12 개월 단위로 조사하 였고 수개월 이후 특별한 증상이 없어 내원하지 않는 분들은 전화문의로 증상 여부를 확인하였으며 술 후 증상과 인공 삽 입물과 관련된 합병증을 조사하였다.

통계처리는 SPSS Windows version 22.0(IBM corporation, Somers, NY, USA)을 이용하여 Mann-Whitney U test와 Fisher 정확검정을 사용하여 양군 간을 비교하였으며, $p$-value 가 0.05 보다 작은 경우를 의미 있는 것으로 판정하였다.

\section{결 과}

성별분포에서 생체 흡수성 고정판만을 사용한 환자군은 남자가 18 명, 여자가 1 명이었으며 생체 흡수성 고정판을 삽입 하고 피브린 글루를 이용하여 고정한 환자군은 남자가 13명, 여자가 3 명이었다. 연령 분포는 생체 흡수성 고정판군은 27.7 세(14 45세)였으며, 생체 흡수성 고정판과 피브린 글루군은 38.6세(18 58세)였다. 골절의 부위는 생체 흡수성 고정판군 에서 좌측이 13예(68.4\%), 우측 6예(31.6\%)로 좌측이 더 많았 고 생체 흡수성 고정판과 피브린 글루군은 좌측이 8예(50\%), 우측이 8예(50\%)로 좌우측이 같았다. 수상 원인은 생체 흡수 성 고정판군에서는 구타 11예(57.9\%), 스포츠 부상 5예(26.3\%), 추락사고가 3예(15.8\%) 순이었고, 생체 흡수성 고정판과 피브 린 글루군은 추락사고 8예(50\%), 구타 6예(37.5\%), 스포츠 부 상 1예(6.3\%), 교통사고 1예(6.3\%) 순이었다(Table 1).

외상 후 수술까지의 기간은 생체 흡수성 고정판군은 $10.47 \pm$ 5.3 일, 생체 흡수성 고정판과 피브린 글루군은 $9 \pm 3.92$ 일이었 으며 수술 시간은 생체 흡수성 고정판군은 $130.79 \pm 34.05$ 분, 생체 흡수성 고정판과 피브린 글루군은 $130.94 \pm 34$.27분으
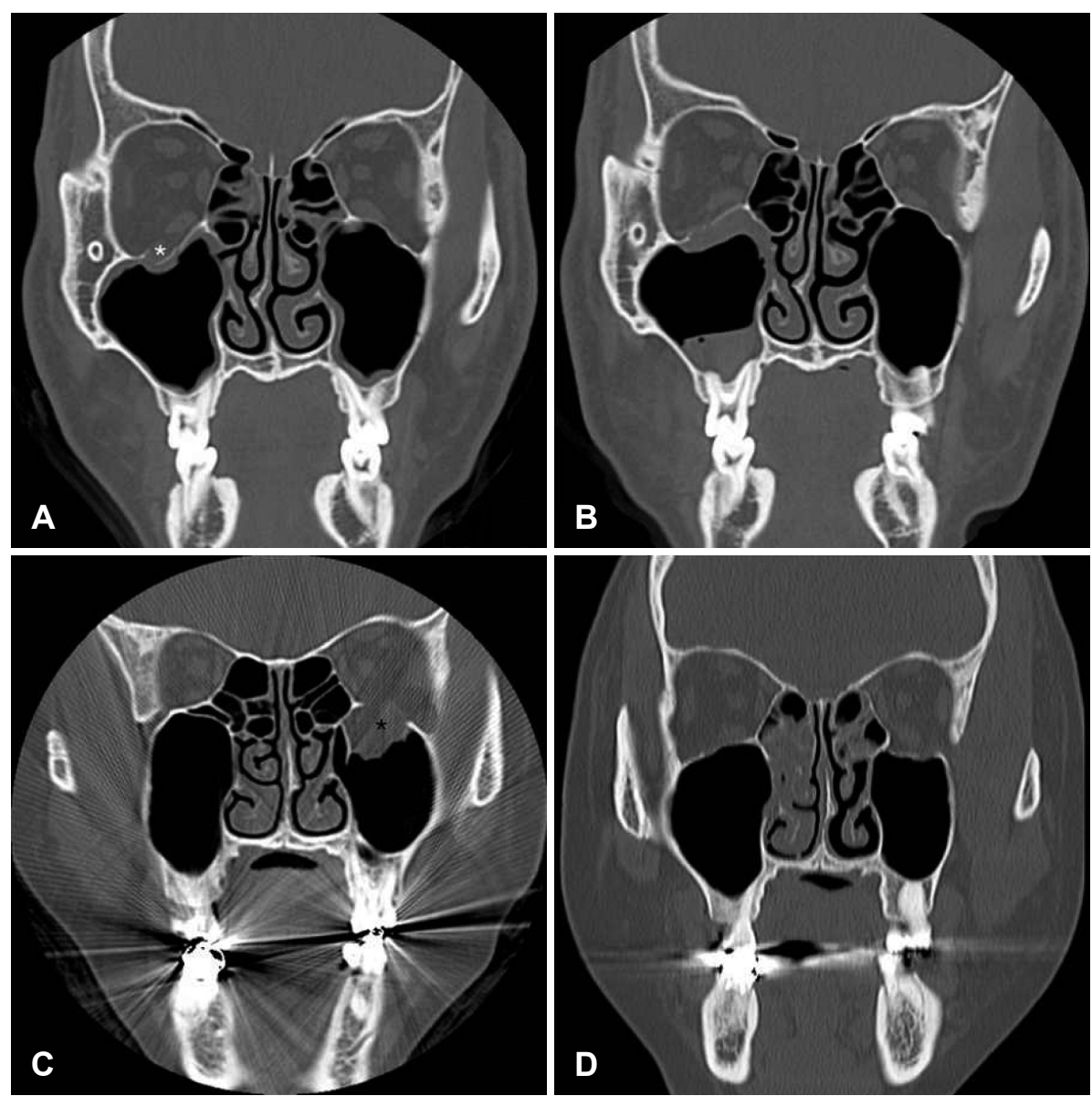

Fig. 2. Preoperative (A and $C)$ and postoperative (B and $\mathrm{D}$ ) coronal CT scans of the blowout fracture of the inferior orbital wall. Orbital floor displacement was classified as: grade I, discrepancy of displacement (white asterisk) below $2 \mathrm{~mm}$ (A and $\mathrm{B})$; grade II, a discrepancy of displacement (black asterisk) above $2 \mathrm{~mm}$ (C and D). 
Table 1. Demographic data of patients

\begin{tabular}{lcc}
\hline & Bioresorbable panel $(n=19)$ & Bioresorbable panel+fibrin glue $(n=16)$ \\
\hline M:F & $18: 1$ & $13: 3$ \\
Age & $27.7 \pm 8.76$ & $38.6 \pm 11.73$ \\
R:L & $6: 13$ & $8: 8$ \\
Cause of trauma (\%) & & \\
Assaults & $11(57.9)$ & $6(37.5)$ \\
Sports & $5(26.3)$ & $1(6.3)$ \\
Falls & $3(15.8)$ & $8(50)$ \\
Traffic accidents & 0 & $1(6.3)$ \\
\hline
\end{tabular}

Table 2. Comparisons of interval between injury and repair, operation time, hospital stay and follow up period in each surgical group

\begin{tabular}{lccc}
\hline & Bioresorbable panel & Bioresorbable panel+fibrin glve & p-value \\
\hline Interval between injury and repair (days) & $10.47 \pm 5.3$ & $9 \pm 3.92$ & 0.37 \\
Operation time (mins) & $130.79 \pm 34.05$ & $130.94 \pm 34.27$ & 0.883 \\
Lengh of hospital stay (days) & $8.58 \pm 2.14$ & $7.56 \pm 4.6$ & $0.034^{*}$ \\
Follow up period (days) & $53.11 \pm 72.39$ & $76.06 \pm 65.08$ & 0.056 \\
\hline
\end{tabular}

$* p<0.05$

Table 3. Comparisons of preoperative and postoperative symptoms in each surgical group

\begin{tabular}{|c|c|c|c|}
\hline Symptoms & Bioresorbable panel $(n=19)$ & Bioresorbable panel+fibrin glue $(n=16)$ & $p$-value \\
\hline \multicolumn{4}{|l|}{ Preoperative (\%) } \\
\hline Periorbital swelling & $18(94.7)$ & $16(100)$ & 1.000 \\
\hline Diplopia & $7(36.8)$ & $7(43.8)$ & 0.678 \\
\hline EOM limitation & $9(47.4)$ & $5(31.3)$ & 0.332 \\
\hline Enophthalmos & $1(5.3)$ & $1(6.3)$ & 1.000 \\
\hline Facial hypoesthesia & $5(26.3)$ & $5(31.3)$ & 1.000 \\
\hline \multicolumn{4}{|l|}{ Postoperative (\%) } \\
\hline Periorbital swelling & $9(47.4)$ & $7(43.8)$ & 1.000 \\
\hline Diplopia & $7(36.8)$ & 0 & $0.009 *$ \\
\hline EOM limitation & $3(15.8)$ & 0 & 0.234 \\
\hline Enophthalmos & $1(5.3)$ & 0 & 1.000 \\
\hline Facial hypoesthesia & $1(5.3)$ & $1(6.3)$ & 1.000 \\
\hline
\end{tabular}

* $p<0.05$. EOM: extraocular movement

로 양군 간에 유의한 차이는 없었으나 입원 기간은 생체 흡 수성 고정판군은 8.58 \pm 2.14 일, 생체 흡수성 고정판과 피브린 글루군은 7.56 \pm 4.6 일로 생체 흡수성 고정판과 피브린 글루 군이 유의하게 짧았다. 수술 후 평균 경과 관찰 기간은 생체 흡수성 고정판군은 53.11 \pm 72.39 일, 생체 흡수성 고정판과 피 브린 글루군은 $76.06 \pm 65.08$ 일로 양군 간에 유의한 차이는 없 었다(Table 2).

\section{술 전 증상 및 술 후 결과}

생체 흡수성 고정판군은 18명(94.7\%)에서 술 전 안구주위 부종 및 자반, 결막충혈이 있었으며 7명(36.8\%)이 복시를 호 소하였고 9명(47.4\%)이 안구운동장애가 있었다. 양안이 $2 \mathrm{~mm}$ 이상 차이가 나는 안구함몰은 1명(5.3\%), 그 외 수상부위 안면
부 감각저하가 5 명(26.3\%)이었다. 생체 흡수성 고정판과 피브 린 글루군에서는 16명 모두에서 술 전 안구주위 부종 및 자 반, 결막충혈이 있었으며 7명(43.8\%)이 복시를 호소하였고 이 중 5명(31.3\%)이 안구운동장애가 있었다. 안구함몰은 1 명 (6.3\%), 그 외 수상부위 안면부 감각저하가 5명(31.3\%)이었으 며 술 전 증상은 양군 간에 유의한 차이는 없었다(Table 3). 생 체 흡수성 고정판군에서 9명(47.4\%), 생체 흡수성 고정판과 피 브린 글루군에서는 7명(43.8\%)이 술 후에 안구주위 부종 및 결막충혈이 발생하였으나 모두 수술 1 주일 이내에 회복되었 다. 수술 후 생체 흡수성 고정판군은 복시가 7명(36.8\%), 이 중 3 명(15.8\%)이 안구운동장애가 있었으며 안구함몰과 안면부 감각저하가 각 1 명씩 있었고 생체 흡수성 고정판과 피브린 글루군은 안면부 감각저하가 1명 있을 뿐 그 외 다른 증상은 
보이지 않았다. 양군 간에 수술 전후의 증상 개선 정도를 비교 해 볼 때 복시 부분에서 생체 흡수성 고정판군에 비해 생체 흡 수성 고정판과 피브린 글루군에서 의미 있는 호전을 보여주 었으며, 그 외 다른 증상 역시 생체 흡수성 고정판군보다 생 체 흡수성 고정판과 피브린 글루군에서 더 많이 호전되는 경 향을 보였으나 통계학적으로 유의하진 않았다(Table 3).

\section{술 전 및 술 후 골절편 위치의 변화}

술 전 안와하벽골절의 정도는 생체 흡수성 고정판군의 경우 17 명(89.5\%), 2명(10.5\%)에서 grade II와 grade I을 보였으며 생 체 흡수성 고정판과 피브린 글루군은 15명(93.8\%), 1명(6.3\%) 에서 grade II와 grade I을 보여 양군 간에 통계적 유의성은 없었다. 술 후 정복된 안와하벽의 위치는 생체 흡수성 고정판 군의 경우 grade I이 10명(52.6\%), grade II가 9명(47.4\%)으로 평가되었으며 생체 흡수성 고정판과 피브린 글루군에서는 grade I이 15명(93.8\%) 그리고 grade II가 1명(6.3\%)으로 평가 되어 양군 간에 통계적으로 유의한 차이를 보였다(Table 4).

\section{재수술 및 합병증}

생체 흡수성 고정판군 총 6예(31.6\%)에서 재수술을 시행하 였다. 1 예에서는 술 후 더욱 심해진 복시와 안구운동장애를 호소하여 술 후 1 일째 재수술을 시행하였으며 생체 흡수성 고정판이 이탈하면서 하사근의 후방부위에 붙는 섬유성 띠 (fibrous band)가 감돈된 것을 발견할 수 있었고 이를 풀어준 다음 생체 흡수성 고정판을 다시 삽입한 후 증상이 호전되었 다. 다른 1 예에서는 술 후 지속되는 복시와 안구운동장애를 호소하여 술 후 2 일째 재수술을 시행하였으며 역시 생체 흡 수성 고정판이 이탈하면서 다시 탈출된 안와 내 조직을 발견 하였고 생체 흡수성 고정판이 쉽게 이탈할 수 없도록 크기를 재조정하여 재단, 삽입한 후 증상이 호전되었다. 나머지 4예에 서는 술 후 개선되지 않는 복시를 호소하여 술 후 2 3일째 재수술을 시행하였으며 골절되지 않고 남은 안와하벽의 삽 입물에 대한 지지력 약화로 인해 생체 흡수성 고정판이 이탈
한 것을 발견할 수 있었고 더 이상 삽입한 생체 흡수성 고정 판을 지지할 남은 구조물이 없다고 판단하여 0.04인치 실리 콘 시트와 0.04 인치 실리콘 튜브를 상악동 내에 거치하여 생 체 흡수성 고정판을 받쳐줌으로써 정복하였고 이후 복시 증 상은 사라졌다. 상악동 내의 실리콘 시트와 실리콘 튜브는 평균 6주가량 후에 제거 수술을 통해 제거되었고 이와 관련 하여 상악동 내 점막의 부종 및 충혈이 있었으나 상악동염 등 특별한 합병증은 없었다. 반면에 생체 흡수성 고정판과 피 브린 글루군에서는 술 후 안구운동장애나 복시, 새로 발생하 거나 악화되는 경우는 발생하지 않았고 재수술 역시 단 1 예도 시행하지 않아 통계적으로 유의한 차이를 보였다(Table 4). 양군 모두에서 수술 후 경과 관찰 기간 중 안와농양, 안와봉 와직염, 부비동염 등 인공 삽입물의 감염으로 인한 합병증은 없었다.

\section{고 찰}

해부학적으로 안와하벽은 안와 내벽보다 더 두껍지만 안와 내벽이 사골동의 격벽화로 지지를 받는 반면 하벽은 S자 형으 로 후반부가 돌출되어 있을 뿐만 아니라 안와하 신경이 통과 하고 중력의 영향 때문에 골절의 빈도가 더 흔하다. ${ }^{8)}$

아직까지 안와하벽골절의 수술 시기 및 적응증, 수술적 접 근 방법에 대하여 학자들마다 논란이 많으며 주로 술자의 경 험 및 선호도에 따라 수술 방법이 결정된다. 현재 안와하벽골 절의 정복에서는 경안와 접근이 많이 시행되어지고 있으나, ${ }^{9}$ 경안와 접근은 시신경 손상의 위험 때문에 안와하벽 뒤쪽 골 절의 정복이 어렵고, 삽입물의 이탈, 안검외반, 반흔 등의 부 작용이 있다. ${ }^{10)}$ 이러한 문제점 때문에 최근 안와하벽골절의 치료에 경상악동 접근법의 필요성이 부각되는 추세이다. ${ }^{1)}$

골절 부위의 결손을 막기 위해 여러 가지 재료를 삽입하는 방법은 안와 골절의 교정에 있어 널리 이용되는 방법이나 Suhk 등 ${ }^{11)}$ 은 안와하벽 면적의 $50 \%$ 이상이고, 안와연(orbital $\mathrm{rim})$ 으로부터 $20 \mathrm{~mm}$ 이상 후방까지 연장된 광범위한 골절이

Table 4. Comparisons of mean discrepancy between fractured bone chip and intact orbital floor based on coronal CT scans and reoperation in each surgical group

\begin{tabular}{lccc}
\hline Mean discrepancy grade & Bioresorbable panel $(\mathrm{n}=19)$ & Bioresorbable panel+fibrin glue $(\mathrm{n}=16)$ & $\mathrm{p}$-value \\
\hline Preoperative (\%) & $2(10.5)$ & $1(6.3)$ & 1.000 \\
Grade I & $17(89.5)$ & $15(93.8)$ & $15(93.8)$ \\
Grade II & $10(52.6)$ & $1(6.3)$ & $0.010^{*}$ \\
Postoperative (\%) & $9(47.4)$ & 0 & $0.022^{*}$ \\
Grade I & $6(31.6)$ & 0 & \\
Grade II & $6(2)$ & & \\
Reoperation & & & \\
\hline
\end{tabular}

$* p<0.05$. Grade I: discrepancy of displacement $<2 \mathrm{~mm}$, Grade II: discrepancy of displacement $>2 \mathrm{~mm}$ 
있으면서 후방의 지지구조가 거의 없거나 적은 경우 삽입물의 이동이 발생하기 쉽다고 하였으며, 본 연구에서도 생체 흡수 성 고정판만을 사용한 수술군에서 삽입물의 이탈로 재수술 이 필요한 경우가 6예 발생하였다.

Yoo 등 ${ }^{12)}$ 은 안와하벽골절의 정복에서 경상악동 접근법 또 는 비내시경 접근법을 통한 상악동 충전법으로 삽입물을 지 지하는 방법으로 교정한 이후 삽입물 이탈의 빈도가 유의하 게 감소하였다고 하였다. 골절 부위 결손을 메우기 위한 삽입 물의 탈출을 막기 위해 경상악동 접근법을 통한 상악동 충 전 방식의 정복에서 여러 가지 충전물이 소개되었지만, 24,5$)$ 상 악동 충전법은 상악동 내 충전물을 제거하는 2 차 수술을 해 야 하고 지지하는 충전물의 전위와 유실, 충전물로 인한 이물 반응으로 염증이 발생할 수 있다는 단점이 있다.5,7,13,14) 그래서 저자들은 두 번 수술해야 하는 한계점을 없애고 삽입물의 이 탈 없이 안정적으로 안와 내용물을 지지하기 위해서는 생체 분해성 및 생체 적합성을 갖는 소재가 필요함을 생각하였고 생체 흡수성 고정판을 삽입한 후 피브린 글루를 도포하여 고 정하는 방법을 고안하였다.

저자들이 사용한 Macropore ${ }^{\circledR}$ 는 polylactic acid의 이성질 체(isomer)인 L-lactic acid와 DL-lactic acid가 70:30 비율로 구성되어 있는 혼성 중합체(copolymer)로 Al-Sukhun 등 ${ }^{15}$ 과 $\mathrm{Hu}$ 등 $^{16)}$ 의 연구에서 생체 분해성 및 생체 적합성을 갖는 소 재이고 골절부에서 충분한 안와벽 지지 효과가 있으면서 뚜 렷한 합병증 없이 안전하게 사용할 수 있는 삽입물이라고 하 였다. 그리고 Rozema 등 ${ }^{17)}$ 이 동물 실험을 통하여 삽입된 poly-lactic acid implant 주위로 19주째에 골형성이 시작되 어 78주 후에는 골조직이 삽입물을 완전히 덮게 된다고 보고 하여, ${ }^{20)}$ Macropore ${ }^{\circledR}$ 삽입 후 약 18 개월 후에 의미 있는 기계 적 지지력을 소실하더라도 장기적인 안정성을 유지하는 데 문제가 없다는 생각을 뒷받침한다. 또한 기존에 보고된 비흡 수성 물질인 Medpor ${ }^{\circledR}$ (Stryker Instruments, Kalamazoo, MI, $\mathrm{USA}$ )를 이용한 안와 골절 정복술과 비교한 연구에서 인공 삽 입물과 관련된 감염 및 유착 등의 합병증이 전혀 발생하지 않 았다는 점에서 생체 흡수성 고정판을 좀 더 안전한 물질로 신 뢰할 수 있다. ${ }^{18,19)}$

다양한 수술영역에서 사용되고 있는 피브린 글루는 생리적 조직접착제로 피브리노겐과 트롬빈이 염화칼슘과 반응하여 수 분 내에 응고 연쇄반응을 유도하고 다양한 성장 인자를 생 산하여 조직 치유를 가속화시키고, ${ }^{20,21)}$ 지혈 및 조직 접합을 도와주어 이식된 뼈에 대한 연조직의 부착을 촉진하고 안면 골 재건에 있어서 안정성과 결합을 증가시켜 악안면성형재건 술에서 널리 사용되고 있다. ${ }^{22-24)}$ 또한 비내시경 수술 후 사골 동에 도포된 피브린 글루가 점막재생과 유착 및 가피 형성의
방지에 효과적이었다는 보고도 있으며, ${ }^{25)}$ 상처 치유 과정에서 이물 반응이나 섬유화 없이 완전히 흡수된다. ${ }^{24,25)}$

저자들은 이러한 특장점을 통해 상악동 내 충전물대신생 체 흡수성 고정판에 피브린 글루를 도포하여 삽입물을 충분 히 지지 및 고정할 수 있다 생각하였고 앞에서 보여준 결과와 같이 생체 흡수성 고정판 단독 사용군과 비교하여 수술 시간 연장 없이 통계적으로 유의한 재수술 시행의 감소와 복시를 비롯한 안와외향골절 관련 증상 부분에서 좀 더 나은 술 후 결과를 안전하게 얻을 수 있었으며 재원 기간 역시 의미 있게 줄일 수 있었다.

생체 흡수성 고정판과 피브린 글루를 사용할 경우 환자의 입장에서는 재료 사용으로 인한 추가적인 경제적 부담을 안 게 될 수 있으나 상악동 내 충전물을 제거하는 2차 수술이 필 요 없고 골절 부위의 결손을 막기 위한 삽입물의 이동을 막 아 재수술과 그 외 여러 합병증을 줄여줄 수 있는 긍정적인 효과를 고려할 때 결과적으로 환자에게 시간적, 금전적 손해 가 되지 않으리라 생각된다.

결론적으로 피브린 글루는 안전성이 확보되어 있으며 지 혈 및 조직접착효과가 강력하고 신속하기 때문에 상처 치유 과정에서 골결손 부위를 메우기 위해 삽입한 생체 흡수성 고 정판에 적절한 고정력을 제공하여 술 후 삽입물의 이동을 방 지하는 효과가 있다. 따라서 광범위한 안와하벽의 골절에서 남아있는 지지구조가 충분하지 않아 안와 삽입물의 이동이 쉽게 예상되는 경우, 생체 흡수성 고정판을 이용한 경상악동 안와하벽골절 정복술에서 피브린 글루의 사용은 생체 흡수 성 고정판을 고정하는 데 매우 유용할 것으로 생각된다.

\section{REFERENCES}

1) Kwon J. Update in treatment of orbital blowout fractures. Korean J Otorhinolaryngol-Head Neck Surg 2011;54(5):317-23.

2) Gray LN, Kalimuthu R, Jayaram B, Lewis N, Sohaey M. A retrospective study of treatment of orbital floor fractures with the maxillary sinus approach. Br J Plast Surg 1985;38(1):113-5.

3) Ikeda K, Suzuki H, Oshima T, Takasaka T. Endoscopic endonasal repair of orbital floor fracture. Arch Otolaryngol Head Neck Surg 1999;125:59-63.

4) Lemke BN, Kikkawa DO. Repair of orbital floor fractures with hydroxyapatite block scaffolding. Ophthal Plast Reconstr Surg 1999; 15(3):161-5.

5) Moon JH, Park SW, Kim YH, Kwon MS, Han CY, Kwon JH, et al. Reduction of the blowout fracture of the inferior orbital wall using elasticity of silicon tube. Korean J Otolaryngol-Head Neck Surg 2003; 46(12):1046-50.

6) Persons BL, Wong GB. Transantral endoscopic orbital floor repair using resorbable plate. J Craniofac Surg 2002;13(3):483-8; discussion 488-9.

7) Kim JY, Choi G, Kwon JH. Transantral orbital floor fracture repair using a folded silastic tube. Clin Exp Otorhinolaryngol 2015;8(3): 250-5.

8) Greenwald HS Jr, Keeney AH, Shannon GM. A review of 128 patients with orbital fractures. Am J Ophthalmol 1974;78(4):655-64. 
9) Courtney DJ, Thomas S, Whitfield PH. Isolated orbital blowout fractures: survey and review. Br J Oral Maxillofac Surg 2000;38(5): 496-504.

10) Brady SM, McMann MA, Mazzoli RA, Bushley DM, Ainbinder DJ, Carroll RB. The diagnosis and management of orbital blowout fractures: update 2001. Am J Emerg Med 2001;19(2):147-54.

11) Suhk JH, Ji SY, Kim TB, Yang WS. Internal fixation of medpor(R) implant for prevention of enophthalmos in posteriorly extended orbital floor fracture. J Korean Cleft Palate-Craniofac Assoc 2008; 9(2):55-61.

12) Yoo JH, Ha W, Lee JW, Yang WS. Clinical significance of orbital inferiomedial blow out fracture. Arch Craniofac Surg 2013;14(1): 24-9.

13) Folkestad L, Westin T. Long-term sequelae after surgery for orbital floor fractures. Otolaryngol Head Neck Surg 1999;120(6):914-21.

14) Otori N, Haruna S, Moriyama H. Endoscopic endonasal or transmaxillary repair of orbital floor fracture: a study of 88 patients treated in our department. Acta Otolaryngol 2003;123(6):718-23.

15) Al-Sukhun J, Törnwall J, Lindqvist C, Kontio R. Bioresorbable poly-L/DL-lactide (P[L/DL]LA 70/30) plates are reliable for repairing large inferior orbital wall bony defects: a pilot study. J Oral Maxillofac Surg 2006;64(1):47-55.

16) Hu J, Liu $X, M a P X$. Induction of osteoblast differentiation phenotype on poly (L-lactic acid) nanofibrous matrix. Biomaterials 2008;29(28): 3815-21.

17) Rozema FR, Bos RR, Pennings AJ, Jansen HW. Poly (L-lactide) implants in repair of defects of the orbital floor: an animal study. $\mathrm{J}$ Oral Maxillofac Surg 1990;48(12):1305-9; discussion 1310.

18) Kwon MS, Moon JH, Kim JG, Kwon JH, Cho JH. Results and complications of the orbital blowout fractures repair. Korean $\mathrm{J}$ Otolaryngol-Head Neck Surg 2006;49(8):802-6.

19) Han JU, Im JS, Suk SH, Kim JY, Kim SW, Park TJ, et al. The surgical results of isolated orbital blowout fractures using bioresorbable poly L-/DL-Lactide 70/30 implant. Korean J Otorhinolaryngol-Head Neck Surg 2014;57(11):759-65.

20) Jeong HS, Moon MS, Lee HK, Kim KS. Use of fibrin glue for open comminuted nasal bone fractures. J Craniofac Surg 2010;21(1):75-8.

21) Spotnitz WD. Fibrin sealant: past, present, and future: a brief review. World J Surg 2010;34(4):632-4

22) Saltz R, Sierra D, Feldman D, Saltz MB, Dimick A, Vasconez LO. Experimental and clinical applications of fibrin glue. Plast Reconstr Surg 1991;88(6):1005-15; discussion 1016-7.

23) Davis BR, Sándor GK. Use of fibrin glue in maxillofacial surgery. J Otolaryngol 1998;27(2):107-12.

24) Zieren J, Castenholz E, Baumgart E, Müller JM. Effects of fibrin glue and growth factors released from platelets on abdominal hernia repair with a resorbable PGA mesh: experimental study. J Surg Res 1999;85(2):267-72.

25) Gleich LL, Rebeiz EE, Pankratov MM, Shapshay SM. Autologous fibrin tissue adhesive in endoscopic sinus surgery. Otolaryngol Head Neck Surg 1995;112(2):238-41. 